\title{
The use of electric drive in urban driving conditions using a hydrogen powered vehicle - Toyota Mirai
}

Vehicles with electric propulsion systems are increasingly more often equipped with solutions that improve their drive system's efficiency. The latest vehicle model with a fuel cell hybrid system - Toyota Mirai was used in this experiment. The design of this vehicle is similar to that of hybrid vehicles in many aspects. However, new fuel cell technologies are being developed for automotive use, including compressed hydrogen tanks and control systems. The article presents an analysis of a fuel cell operation during vehicle startup and driving, with particular emphasis on the hydrogen injection strategy of the three fuel injectors used in the fuel cell. The fuel cell interaction with the high-voltage battery has also been characterized. It has been shown that increase in the electrical supply voltage of the vehicle's electric motor can be observed at high torque values of the electric motor. The maximum voltage gain - approximately three times (up to about $650 \mathrm{~V}$ ) - allows for double the torque of the drive system compared to the standard value.

Key words: fuel cell, HEV vehicle, hydrogen fuel

\section{Introduction}

The transport development strategy, approved for implementation by the European Commission, calls for the reduction of greenhouse gas emissions from the transport sector. Realization of these assumptions with the conventional drive systems will not be possible. Leading car manufacturers, aware of the challenges they face, to work intensively on alternative drives for passenger vehicles. The introduction of a hybrid drive in 1997 by the major car manufacturer, Toyota, was the effect of this new research strategy [8]. The combination of an electric and conventional drive system has made it possible to significantly reduce the atmospheric $\mathrm{CO}_{2}$ emissions. In the first generation of Toyota Prius the average $\mathrm{CO}_{2}$ emission was 120 $\mathrm{g} / \mathrm{km}$ [1] while the latest version of its fourth generation produces merely 70 grams per kilometer [2]. This company estimates that since the introduction of the Prius, the replacement of 10 million conventional-type diesel cars with 10 million hybrid cars has reduced the $\mathrm{CO}_{2}$ emissions by over 77 million tons. The fact that more and more manufacturers are using hybrid drives in Europe, North America and Asia serves as a confirmation of this drive's potential.

Despite the popularity of this kind of drive system, the requirements set by the European Commission to reduce carbon dioxide emissions will still be impossible to reach. It is only the task of creating a zero-emission vehicle, posed to the car manufacturers, that will eventually allow for the implementation of this transport development strategy. All leading manufacturers want to achieve these goals by putting vehicles with electric drives into mass production. The main issue is: what will be the energy carrier - automotive battery or hydrogen.

Hydrogen as an energy carrier allows a vehicle - at a standard refueling pressure of $70 \mathrm{MPa}$ and a hydrogen mass of $5 \mathrm{~kg}$ - to cover a distance up to $550 \mathrm{~km}$. The use of such high pressure requires special tank designs that are already mass-produced. The established hydrogen refueling standards for passenger cars also requires a larger investment in the construction of a hydrogen refueling stations. The main advantage of this standard is the time of refueling
5 kilograms of hydrogen, i.e. filling the tank from 0 to $100 \%$ which takes about 3 minutes. This is the main argument for this type of energy carrier, as opposed to the time consuming charging of electric vehicles. The safety of using fuel cell powered vehicles is also supported by the fact that they are actually refueled by drivers without any supervision. The construction of self-service stations was adopted as a standard solution.

Does this energy carrier already provide a clear and unambiguous alternative to conventional propulsion? The hydrogen production process itself is known and popular. It can be produced, from coal, through the electrolysis of clean water, even by composting municipal waste. The challenge remains to find and popularize a method that meets two mutually exclusive criteria: the purity of hydrogen and its price. At present, the cost of hydrogen is about 9 Euro per kilogram, which makes the cost of operation comparable to the operating costs of a vehicle with a 1.8 $\mathrm{dm}^{3}$ displacement petrol engine.

The widespread use of hydrogen as a source of energy requires, in some parts of the world, the further development of the hydrogen refueling station infrastructure and, in many other parts, building and establishing this infrastructure from scratch.

The use of a high-voltage battery as an automotive energy carrier requires finding a solutions to the fundamental problems of the vehicle's range and battery charging time. Although research aiming to eliminate these problems has been ongoing for over a century, they have yet to be effectively overcome. The latest generation of batteries, not only used by Tesla, provide a range of 150-200 km after just 30 minutes of charging time. The maximum range of the vehicle is up to $450 \mathrm{~km}$, but it takes at least a few hours to charge the battery to full (with three-phase power supply) or even upwards to 30 hours (for normal household use). In order to reach the $200 \mathrm{~km}$ range after only 30-minute charging it becomes necessary to use super-fast chargers. Their charging time shortens the full recharge time to 4.5 hours. The power requirement for one station, however, is $480 \mathrm{~V} /$ $200 \mathrm{~A} \times 3$. 
Undoubtedly, the construction of fast charging stations, usually referred to as superchargers, and the use of supercapacitors are currently considered as the best solution for obtaining a large range of the vehicle with a fully charged battery. Nevertheless, this technology also requires the construction of a charging station infrastructure. It is also extremely important to provide energy for the infrastructure to do its job. It is necessary to build a power grid with a very efficient current source - which is also a technical and economic challenge.

For the person owning and driving a car, the important are parameters such as: the price of fuel, the vehicle range, the availability of fuel and the ease of refueling. For the considered energy carriers, the current price and availability of speak for the use of batteries. This is due to the fact that the initiative of construction of the electric vehicle charging infrastructure had already been undertaken as well as the incentive in the form of a reduced cost recharging or even free sources of electricity that have been provided.

By contrast, hydrogen as an energy carrier that is being distributed to fuel cells in the automotive industry has an undoubtful advantage in the form of fast refueling and a much larger vehicle range after refueling. The poor availability of hydrogen refueling stations is due to the very short history of this technology and as a result of its dynamic development. Hydrogen as fuel looks to have a huge future ahead, merely by the fact that it is possible to produce it in the process of waste disposal, and waste is a big problem for our civilization.

Production of the Toyota Mirai vehicles started in Japan in December of 2014, and the sales in the US in the following year. In Europe, the first vehicles were sold in 2015 in Great Britain, Germany and Denmark, and in 2016 also in Belgium. In the same year Toyota Mirai was launched in Norway and Sweden. There are 5 hydrogen refueling stations in Norway. It is estimated that by 2020 there will be more than 20 of them. Sweden has hydrogen refueling stations in Stockholm, Gothenburg and Malmo. Based on
Toyota data, it is estimated that 700 hydrogen-powered vehicles were sold in 2015 and about 2,000 in 2016. The sale values are expected to reach about 3,000 vehicles in 2017 , with an increase to 30,000 in 2020 .

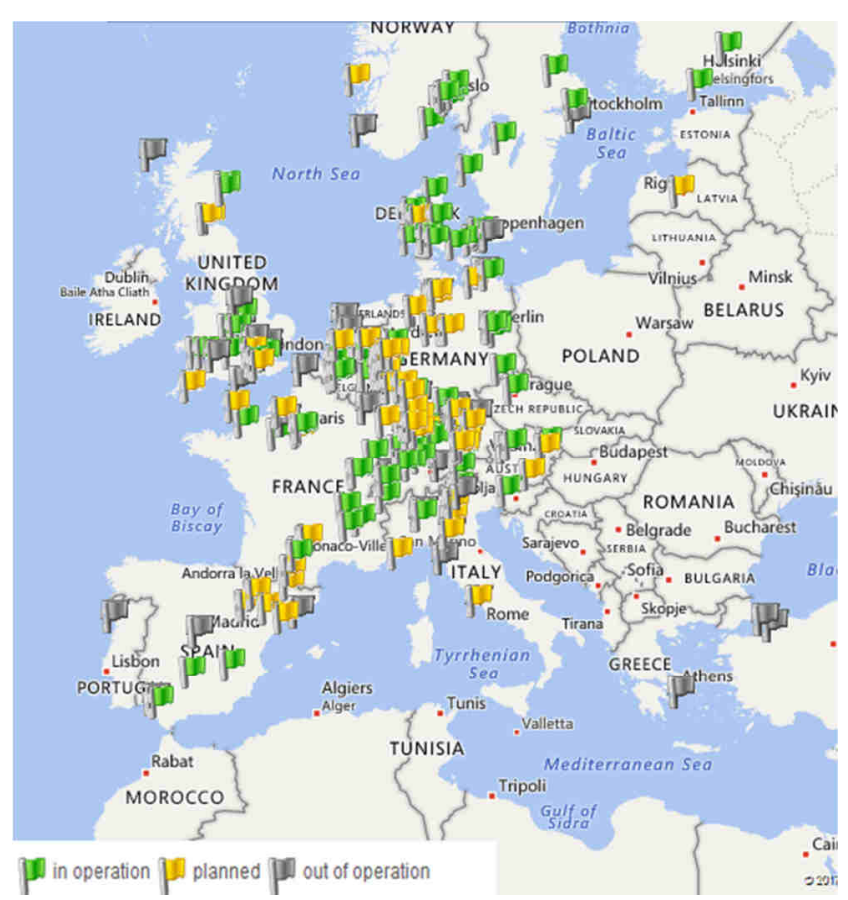

Fig. 1. Map of hydrogen refueling stations in Europe [4]

Two hydrogen tanks with a pressure of $70 \mathrm{MPa}$ were used in the Toyota Mirai vehicle (Fig. 2). Thus the largest unit mass density of compressed hydrogen was obtained. The voltage from the fuel cell stack is converted to 650 volts and fed to the electric AC motor. Technical fuel system data of the vehicle with fuel cells is presented in Table 2.

Table 1. Fuel cell vehicles available on the automotive market

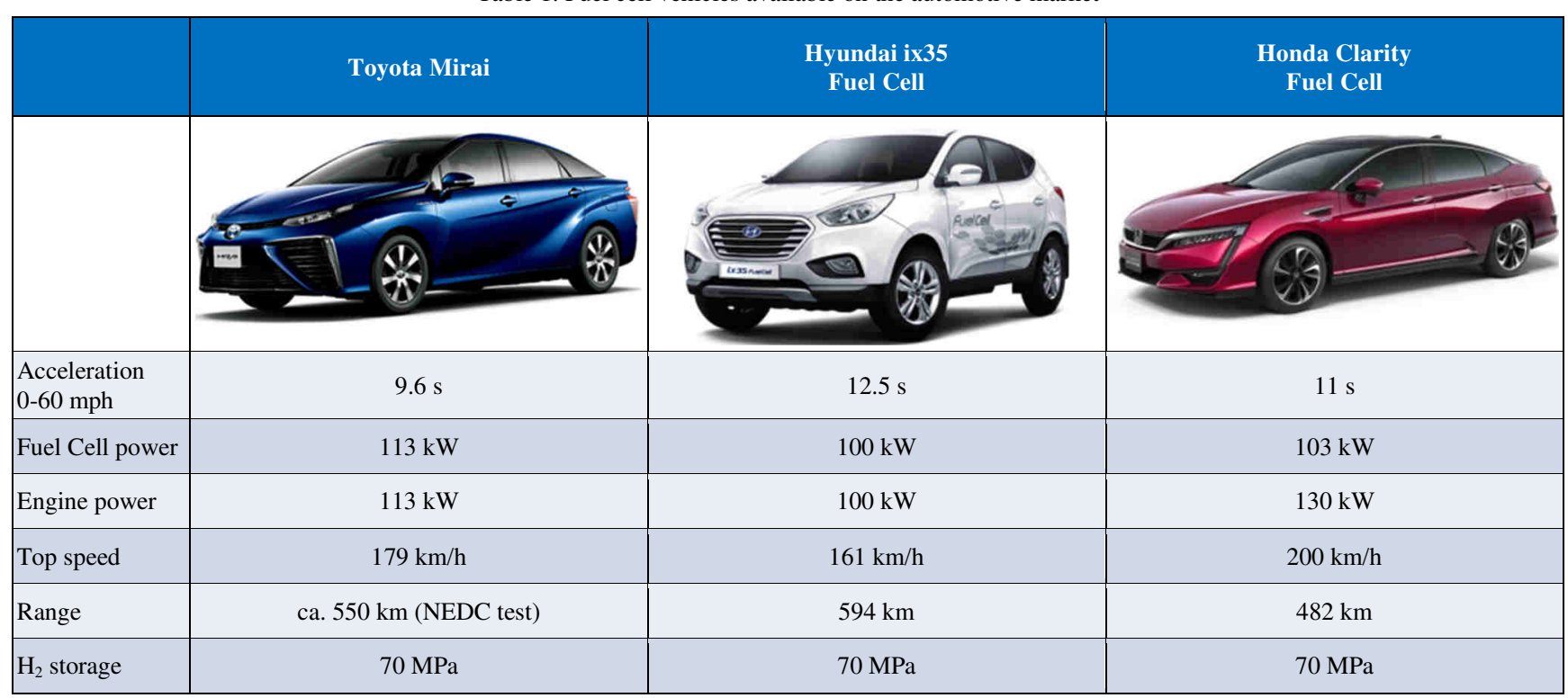


The latest fuel cell drive solutions include more electronic controls than their predecessors. Previous versions of drive development (Fig. 3 - left) had a fuel cell and an inverter that connected directly to the electric motor and fed with the same voltage. The current solution uses a voltage boost, which allows to increase the electric motor supply voltage up to $650 \mathrm{~V}$.

In the new generation of fuel cells, some parts were eliminated and others significantly consolidated, which simplified the whole device structure (Fig. 4).

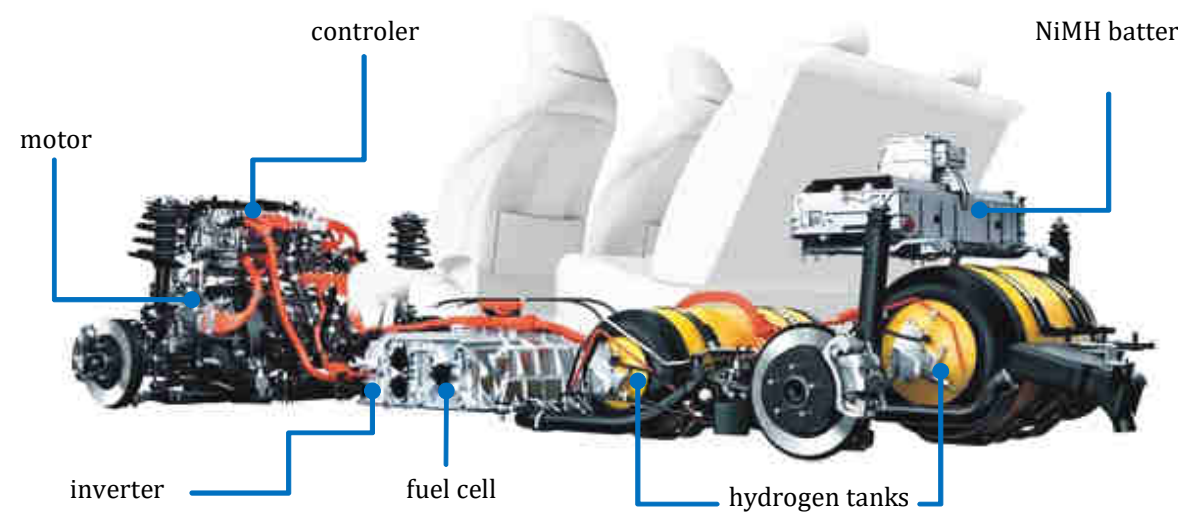

Fig. 2. Components distribution of the Toyota Mirai hydrogen system [6, 7]

Table 2. Toyota Mirai vehicle drive system characteristics [7]

\begin{tabular}{|c|c|c|}
\hline \multicolumn{2}{|l|}{ Parameter } & \multirow{2}{*}{$\begin{array}{c}\text { Value } \\
1850 \mathrm{~kg}\end{array}$} \\
\hline Vehicle & mass & \\
\hline & maximum speed & $179 \mathrm{~km} / \mathrm{h}$ \\
\hline Vehicle range & type approval cycle & approx. $550 \mathrm{~km}$ (NEDC test) \\
\hline \multirow[t]{5}{*}{ Fuel cell } & type & PEM (polymer electrolyte) \\
\hline & power & $114 \mathrm{~kW}$ \\
\hline & power density & $2.0 \mathrm{~kW} / \mathrm{kg} ; 3.1 \mathrm{~kW} / \mathrm{dm}^{3}$ \\
\hline & cell number & 370 \\
\hline & humidification & Internal circulation \\
\hline \multirow[t]{3}{*}{ Electric motor } & type & synchronous AC \\
\hline & maximum power & $113 \mathrm{~kW}$ \\
\hline & maximum torque & $335 \mathrm{~N} \cdot \mathrm{m}$ \\
\hline Battery & type & $\mathrm{NiMH}$ \\
\hline Hydrogen storage & volume of tanks pressure/mass & $\begin{array}{l}\text { front }-60 \mathrm{dm}^{3}, \\
\text { back }-62,4 \mathrm{dm}^{3} \\
70 \mathrm{MPa} / 5 \mathrm{~kg} \mathrm{H}_{2}\end{array}$ \\
\hline Refueling & time & $3 \min$ \\
\hline
\end{tabular}
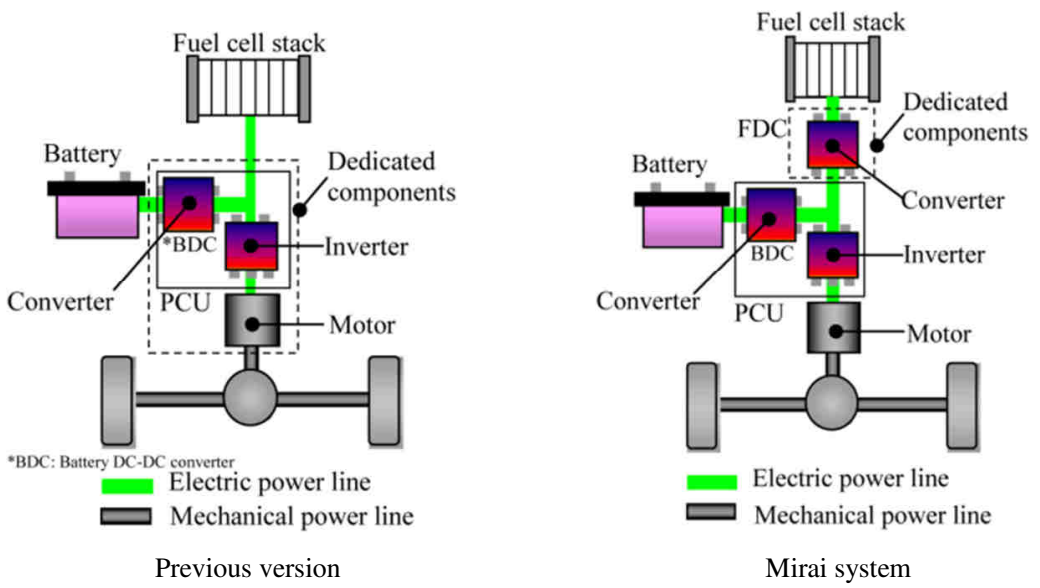

Fig. 3. Generations of Toyota vehicles fuel cell configuration [3] 


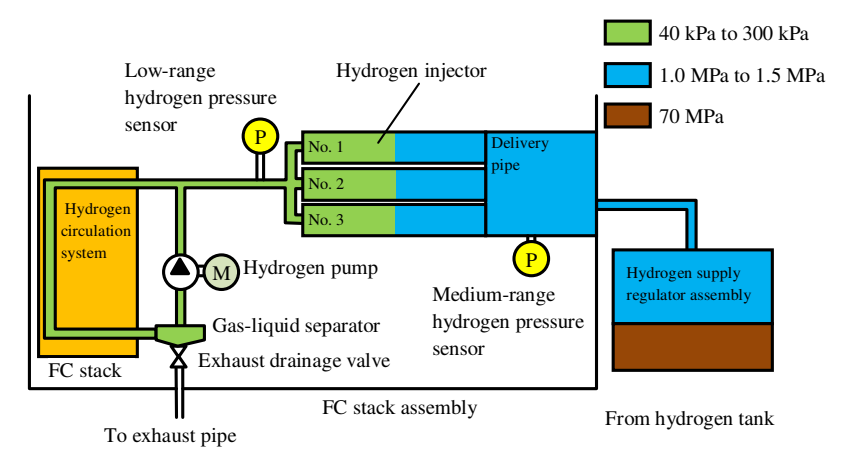

Fig. 4. The fuel cell power supply system schematic [5, 9]

Toyota Fuel Cell System (TFCS) is the world's first fuel cell system without an external humidifier. The fuel cell stack control and the control system was refined so that the water formed at the bottom of the cathode was transported to the front of the upper cathode part via internal circulation through the anode. The characteristic feature of the fuel cell system used in the tested vehicle is the three hydrogen injectors, that operate depending on the load on the system and their operation is the basis for the analysis carried out in the article.

Figure 5 shows the possible driving modes of the first mass-produced fuel cell vehicle. These modes are analogous to modes in hybrid vehicles, except that the function of the energy generator is to fill the fuel cell stack (as opposed to the diesel engine in HEV vehicles). The modes are: standstill loading, starting, normal driving, braking (energy recovery) and acceleration. Block diagrams indicate the systems used to drive the vehicle when in the driving mode. Two directions of energy flow are possible: the use of energy - in the form of hydrogen or electricity stored in a high-voltage battery, and the recovery of energy to charge the HV battery.
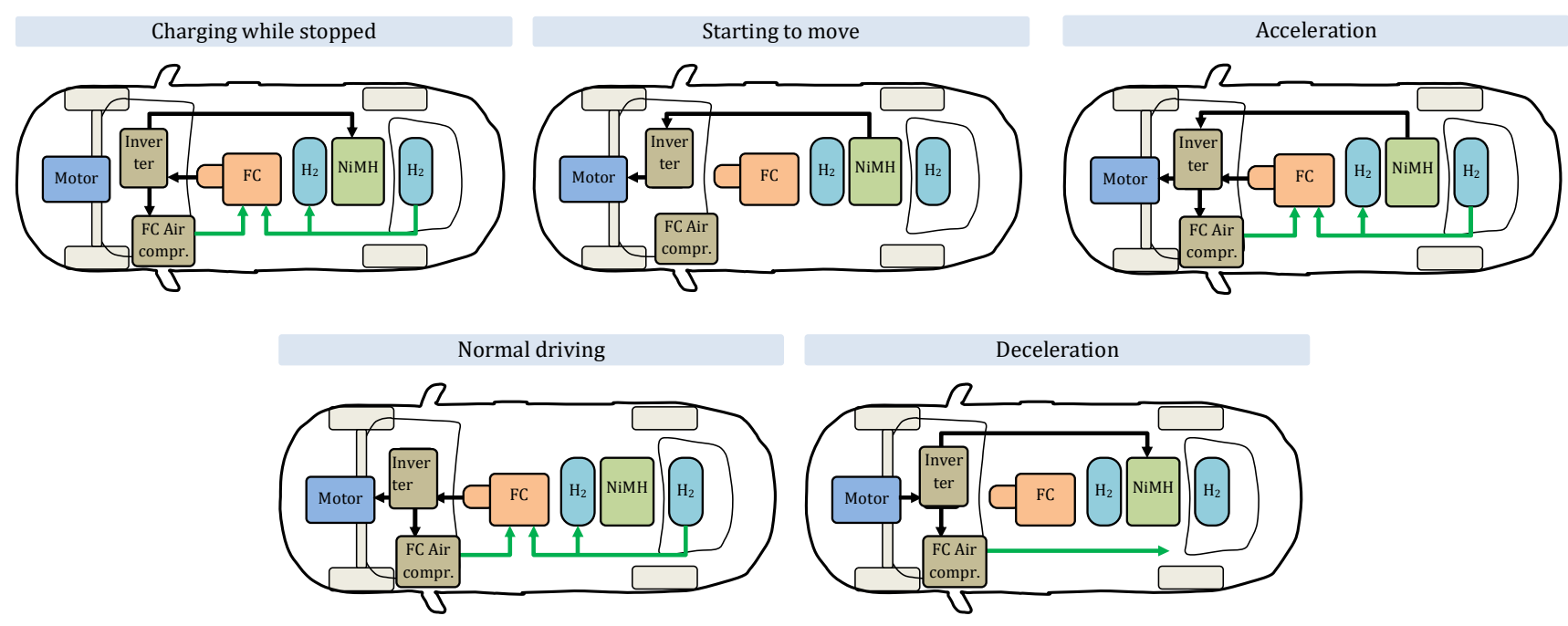

Fig. 5. Drive mode of Toyota Mirai [6]

\section{Fuel cell tests}

The aim of the fuel cell tests for the vehicle was to analyze the operating conditions of the fuel cell in relation to its power supply. Due to the use of three hydrogen injectors in the supply system, the control method was interesting.

The study was conducted in several vehicle operating states, in each case analyzing:

a) starting the fuel cells,

b) standard operating conditions of a fuel cell,

c) cooperation of the fuel cell with energy storage systems.

\section{Fuel cell start}

The fuel cell analysis was performed during the first test drive of the Toyota Mirai vehicle in Poland (the vehicle mileage was approximately $3,000 \mathrm{~km}$ at the time). Because of the limited amount of hydrogen and the short time of vehicle availability, the study was performed during the vehicle presentation in Warsaw. Drive data registration was based on the use of diagnostic monitors (FC - Fuel Cell and FCDC - Fuel Cell Direct Current) implemented in the OBD system. Recording of selected cell parameters from the presented diagnostic monitors was done using an OBD connector and a computer equipped with TechStream software. The number of recorded parameters affects the frequency of data recording. In the presented studies this frequency was:

- 8 to $20 \mathrm{~Hz}$ when recording 51 parameters of the FC monitor,

- 8 to $16 \mathrm{~Hz}$ when recording 91 parameters of the FCDC monitor.

The Toyota Mirai vehicle drive system analysis was performed in fuel cell start-up conditions. The first $20 \mathrm{sec}-$ onds of operation after the system start were analyzed.

The fuel cell start-up began from the state of being switched off completely (as seen by the level of minimum voltage in Fig. 6). Within seconds (2-3 seconds), the value of the voltage generated by the cell stack was $315 \mathrm{~V}$ with a current of $32 \mathrm{~A}$. The rated power $(10 \mathrm{~kW})$ is $10 \%$ of its maximum power. After a 10 second period, the current generated from the fuel cell increased (up to $40 \mathrm{~A}$ ), which increased the power to about $13 \mathrm{~kW}$. These conditions require only hydrogen injection by one injector placed in the power supply (Fig. 4). 


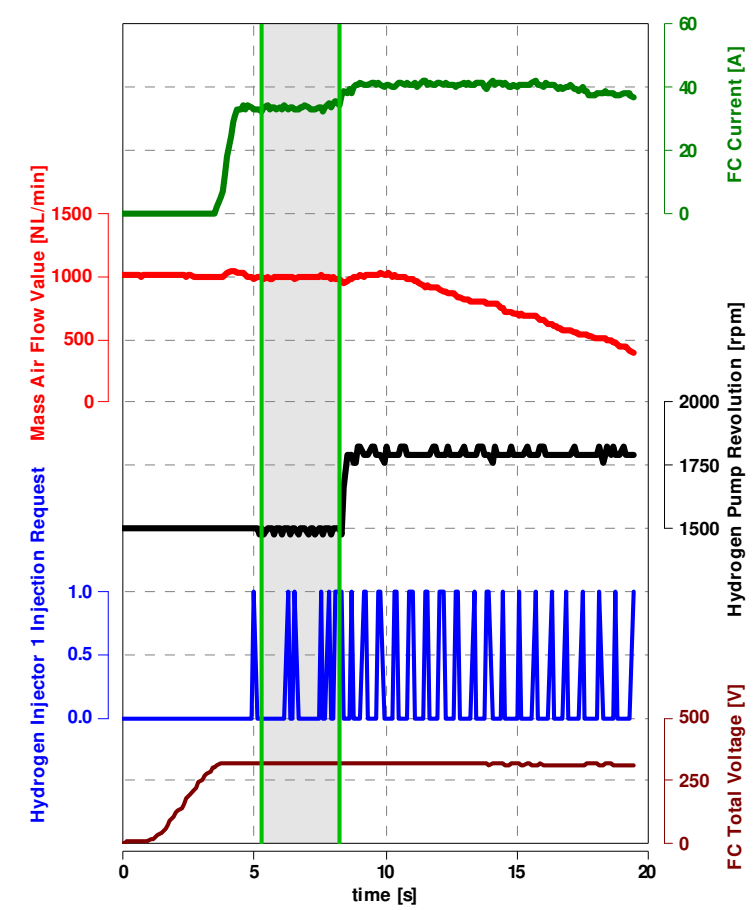

Fig. 6. Changes in fuel cell operating parameters during start-up (vehicle stopped)

Maintaining the operating parameters of the cell after its start-up requires an increased rotational speed of the hydrogen pump (from 1500 to $1800 \mathrm{rpm}$ ) and a much higher frequency of hydrogen injection by the injector 1 . The supply of hydrogen is performed at a pressure of $122 \mathrm{kPa}$ and the air pressure is maintained at $100 \mathrm{kPa}$.

\section{Fuel cell driving operating conditions}

\subsection{Analysis of a fuel cell operation}

The drive operation evaluation began with an analysis of the test vehicle traffic conditions. Figure 7 shows the comparison of the conditions of the four Toyota Mirai routes. For three of those routes (routes 1, 2 and 3) the maximum traveling speeds are comparable and reach 50 $\mathrm{km} / \mathrm{h}$. On these routes the time spent stationary is also close in value (equal to $50 \%$ of the total test time) - Fig. $7 \mathrm{a}$. Route 4 is characterized by an increased maximum vehicle speed. The test duration values are varied and range from 160 to 330 seconds respectively. The analysis of the time density of three driving phases, divided into: driving without acceleration $(\mathrm{a}=0)$, acceleration $(\mathrm{a}>0)$ and braking $(\mathrm{a}<0)$ indicates that each drive had a similar driving parameters. In particular, routes 1-3 have a time density of up to $10 \%$ at constant speed and about $20 \%$ at acceleration and deceleration each.

The fuel cell power analysis shown in Fig. 8 during vehicle acceleration indicates a high level of its performance.

Maximum power of the fuel cell during acceleration is reached after 3.5 seconds. Hydrogen injectors are switched on gradually with the power demand. The third injector was used only after obtaining about $70 \mathrm{~kW}$ cell power generation. With the increase in electric current, the maximum voltage of the cell is reduced, which is in line with the typi- cal characteristics of its operation. Resistance losses then increase, thus limiting the voltage value when increasing the current output [5]. The maximum current of the cell is $468 \mathrm{~A}$ at $244 \mathrm{~V}$. The vehicle speed under these conditions was only $40 \mathrm{~km} / \mathrm{h}$.

a)

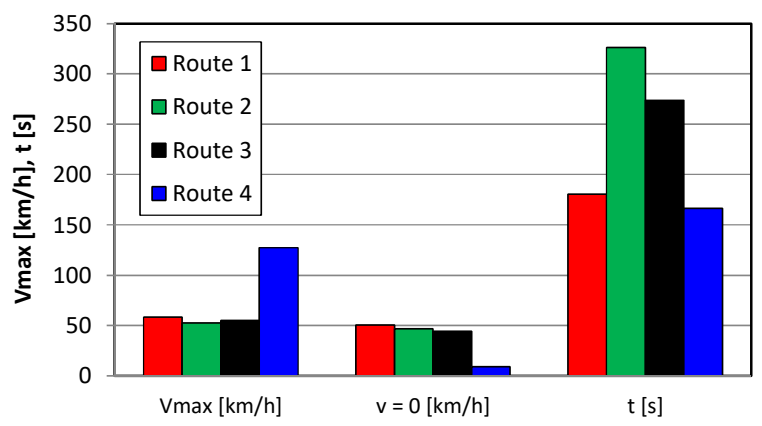

b)

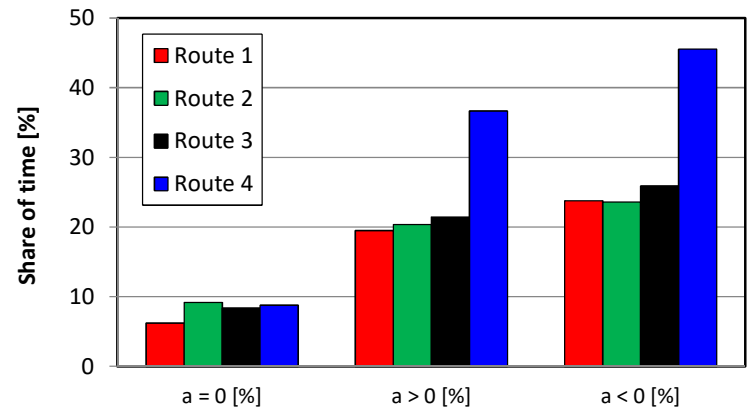

Fig. 7. Road test results of the Toyota Mirai vehicle: a) the vehicle speed, b) the vehicle acceleration time density (excluding the vehicle being stationary)

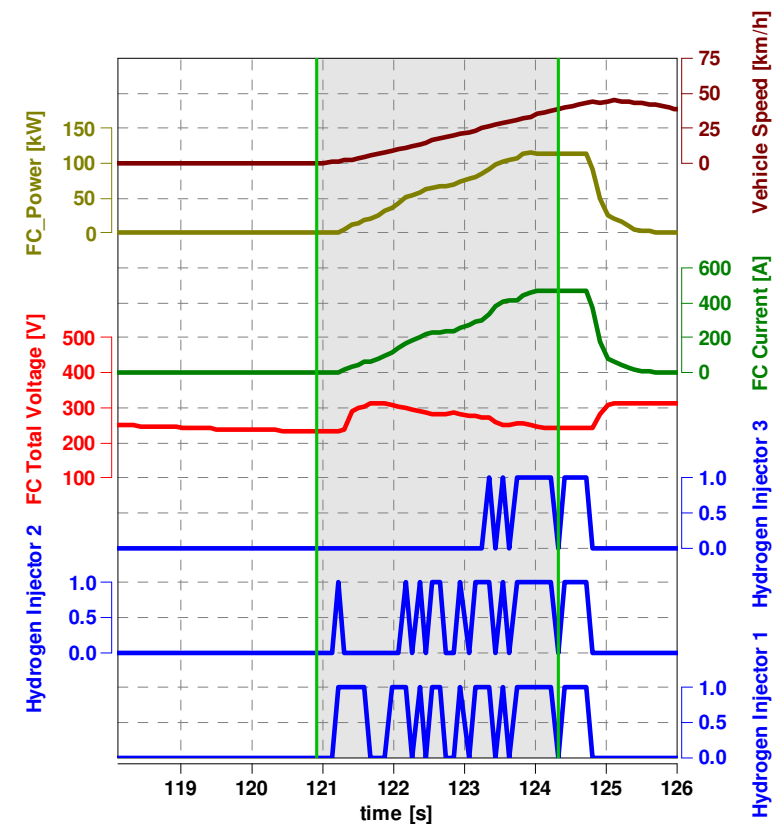

Fig. 8. Example of changes in hydrogen fuel supply (three injectors) against speed variations (average speed) of driving a Toyota Mirai (route 1)

The analysis of the hydrogen injectors operation relative to the driving conditions is shown in Fig. 9. For each test run of different instantaneous speeds and the resulting accelerator pedal position, the work of the individual hydro- 
gen injectors is shown. On this basis, the use of injectors was evaluated based on the position of the accelerator pedal. It was assumed that this value was proportional to the load on the propulsion system.

The analysis was conducted for several acceleration pedal positions: $0 \%, 0-25 \%, 25-50 \%, 50-75 \%$, and $75-100 \%$. Data obtained from this analysis indicate the use of two injectors mainly. The third injector is only used during the final range of accelerator pedal position.
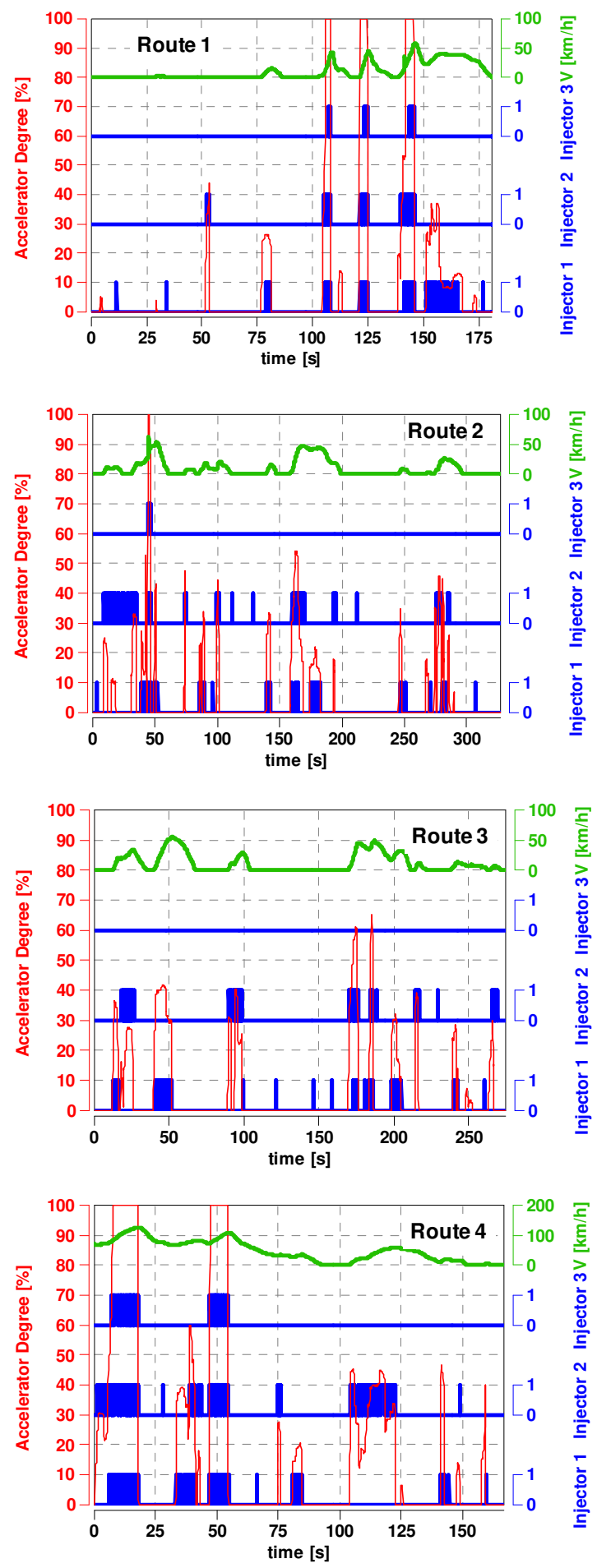

The results shown in Fig. 9 indicate the low speed of the vehicle forcing the third injector to operate.

An analysis was also carried out to summarize the effect of the speed and load on the operating conditions of hydrogen fuel injectors in the fuel cell. Injectors 1 and 2 are operated at each tested vehicle speed and for loads ranging from 0 to $100 \%$ (Fig. 10). The use of injector no. 3 is only required for loads exceeding $60 \%$, which were respective of vehicle speeds in the range of 25 to $130 \mathrm{~km} / \mathrm{h}$.
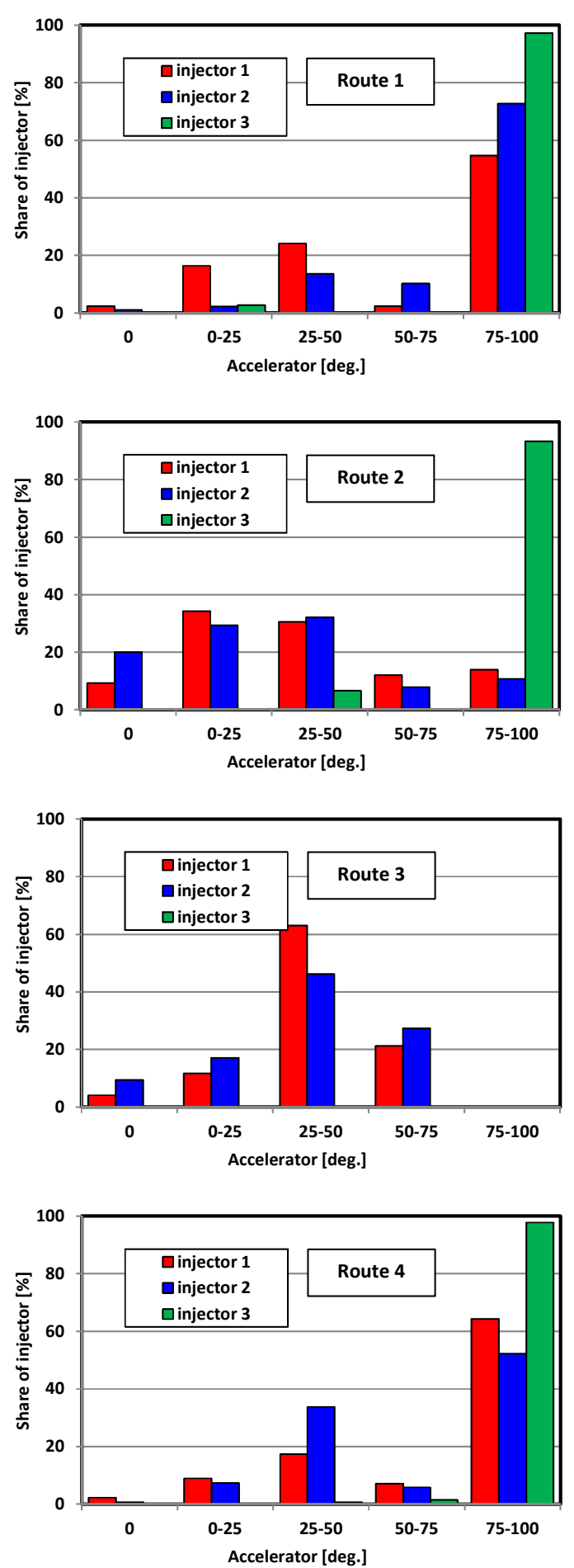

Fig. 9. Analysis of the fuel cell hydrogen power supply conditions by three injectors, along with the injector operating time densities (accelerator pedal positions) 
a)

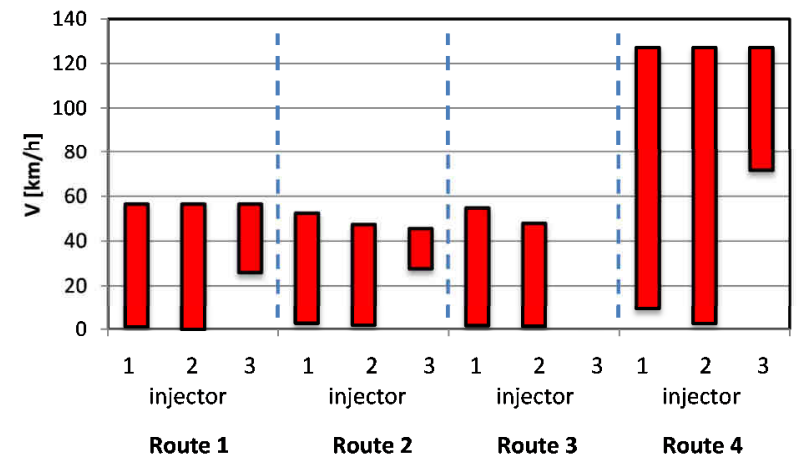

b)

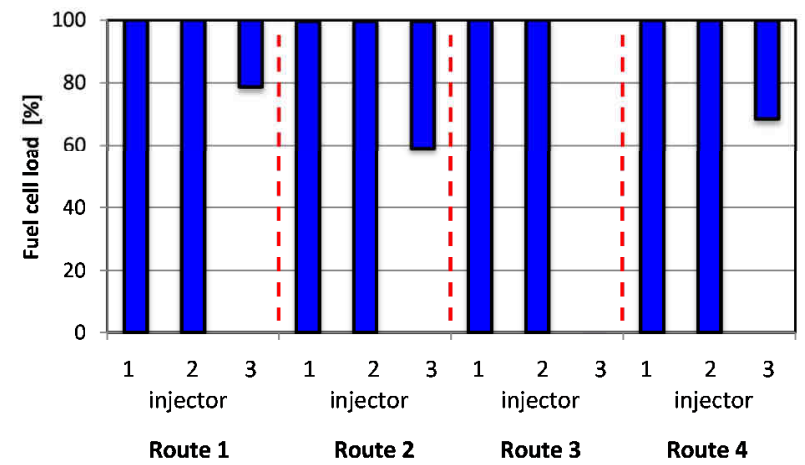

Fig. 10. The influence of vehicle speed (a) and fuel cell load (b) on operating conditions of the hydrogen fuel injectors in the fuel cell

3.2. The interaction of fuel cell and high-voltage battery

The hydrogen drive configurations shown in Fig. 3 indicate that the current systems will use so-called boosts (analogous to hybrid drives) to increase the voltage applied to the electric motor. The fuel cell DC-DC converter (FDC) increases the voltage from the fuel cell up from a maximum of 315 volts to 650 volts. This arrangement allows to double the power of the electric motor driving the vehicle. The conditions for this voltage gain during the operation of the Mirai Toyota system are shown in Fig. 11. It is evident that during vehicle acceleration, the input voltage to the FDC achieves a maximum value (about $315 \mathrm{~V}$ ), while the output of the converter is above $600 \mathrm{~V}$. Additionally, the highvoltage battery operation is noted to aid the fuel cells discharging during acceleration (positive current values) and charging during most braking maneuvers. Despite varying driving conditions, the battery charge level is maintained at $52-62 \%$. This level of charge is also used in hybrid vehicles, which extends the battery lifetime.

Based on the above relationships, the HV battery operating conditions have been analyzed. According to Fig. 12a, the charging of the battery is carried out at increased voltage to about $315 \mathrm{~V}$ (fuel cell operating voltage). Significant battery charge time applies to small charging currents up to $50 \mathrm{~A}$. Its discharge consists in using a current of up to $20 \mathrm{~A}$, however, the maximum values exceed $120 \mathrm{~A}$.

The electric motor operating conditions indicate the use of its full characteristics (Fig. 12b). Regenerative braking mainly occurs in areas of small torque values and in the range of average speeds.

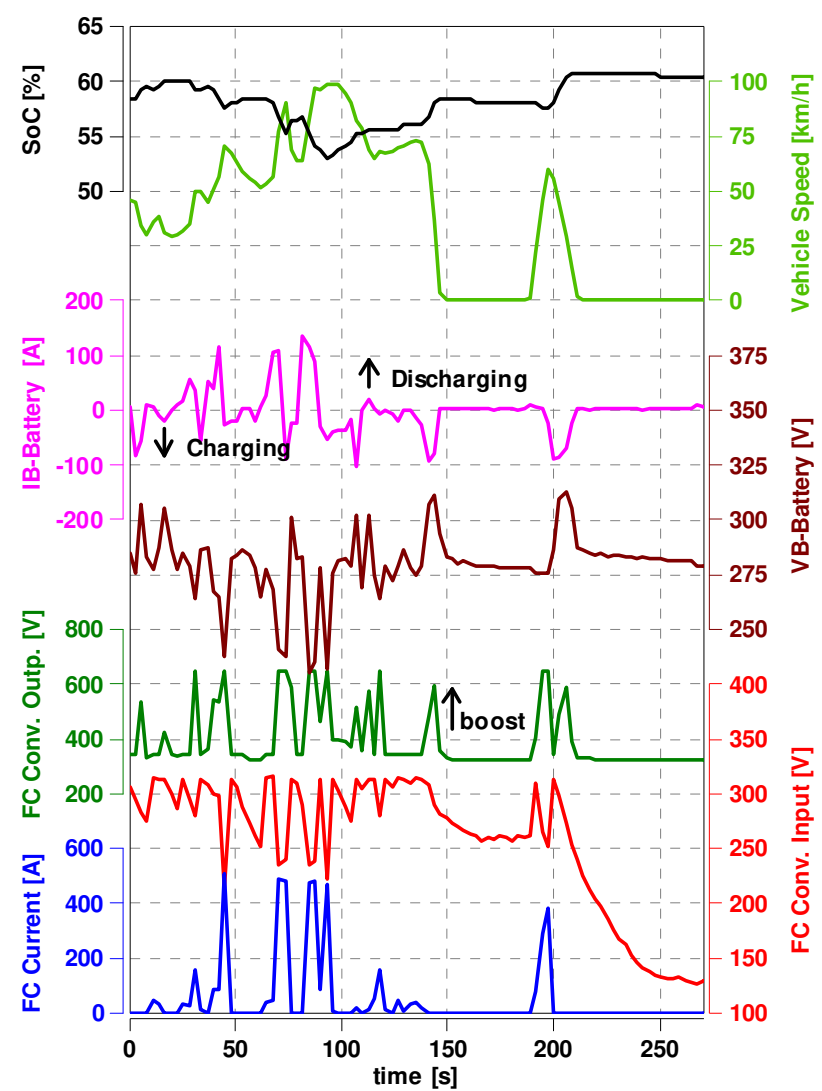

Fig. 11. Operating conditions for the voltage boost circuit for the voltage generated by the fuel cell

a)

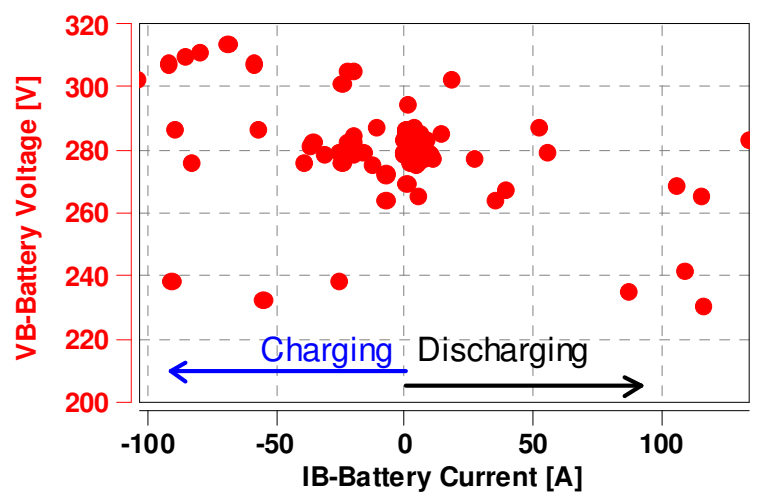

b)

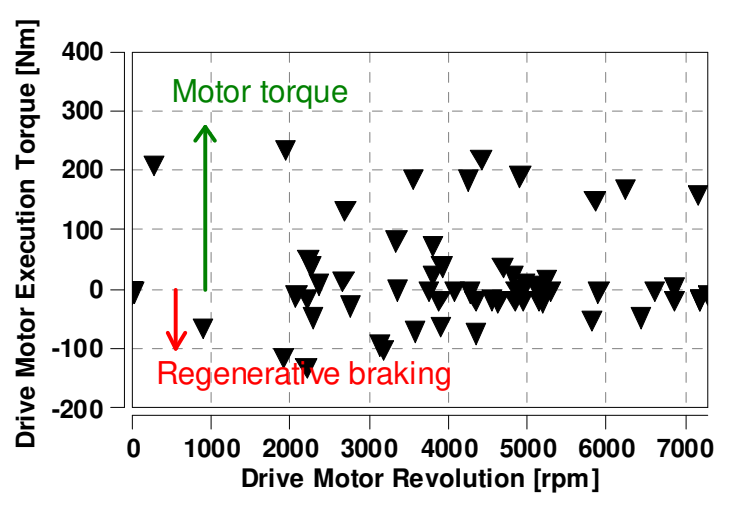

Fig. 12. Operating conditions of the systems: a) high-voltage battery, b) electric machine acting as a motor or generator 


\section{Conclusions}

The Toyota Mirai is the first mass-produced vehicle to feature three independent fuel cell hydrogen injectors. An analysis of the fuel cell system in the vehicle in typical traffic conditions allows to pinpoint the key aspects of this system's operation:

1. The maximum value of the fuel cell voltage $(315 \mathrm{~V})$ when moving from zero is obtained after approximately 4 seconds during the vehicle start-up.

2. The full power of the fuel cell for vehicle acceleration is available after about 3.5 seconds after the vehicle has stopped (fixed operating conditions of the fuel cell).

3. The use of three hydrogen injectors allows for a wide range of possible ways of obtaining the desired flow of hydrogen for the fuel cell supply; The third injector is activated only during a high fuel cell load values at 75$100 \%$ of the accelerator pedal position. Analysis of the results indicates that the third injector is only running at speeds exceeding $35 \mathrm{~km} / \mathrm{h}$.

4. Equipping the power management system with a voltage boosting circuit for the electric motor power supply allows the voltage to be increased from $315 \mathrm{~V}$ to $650 \mathrm{~V}$. The driving conditions that necessitate the operation of the so-called boost is rapid acceleration of the vehicle regardless of the charge level of the high-voltage battery.

Due to the limited time availability of the vehicle for the study future research will be conducted on both the chassis dynamometer in the standardized NEDC test as well as in real vehicle driving conditions at comparable distances. Then the results of the study will be comparable with the results from hybrid vehicles already tested by the Authors. This analysis will allow for a complete assessment of the propulsion system's energy consumption relative to other vehicles. The limitation in carrying out such tests is, however, that there is currently no infrastructure for refueling such vehicles in Poland.

The study presented in this article was performed within the statutory research (contract No. 05/52/DSMK/0265).

\section{Acknowledgements}

The authors would like to thank Toyota and Lexus Academy in Toyota Motor Poland Company Sp. z o.o. in Warsaw for their provision of an vehicle for testing.

\section{Nomenclature}

$\begin{array}{llll}\text { a } & \text { acceleration } & \text { IB } & \text { battery current } \\ \mathrm{AC} & \text { alternating current } & \text { NiMH } & \text { nickiel hydride battery } \\ \mathrm{CO}_{2} & \text { carbon dioxide } & \text { OBD } & \text { on board diagnostic } \\ \mathrm{FC} & \text { fuel cell } & \text { TFCS } & \text { Toyota Fuel Cell System } \\ \text { FCDC } & \text { fuel cell direct current } & \mathrm{V} & \text { speed } \\ \text { FDC } & \text { fuell cell direct current converter } & \text { Vmax } & \text { maximum speed } \\ \mathrm{HEV} & \text { hybrid electric vehicle } & \mathrm{t} & \text { time } \\ \mathrm{HV} & \text { high voltage } & \mathrm{VB} & \text { battery voltage }\end{array}$

\section{Bibliography}

[1] Approval of a vehicle Toyota Prius: e11*98/14*0131*04.

[2] Approval of a vehicle Toyota Prius: e11*2007/46*2971*01.

[3] HASUKA, Y., SEKINE, H., KATANO, K., NONOBE, Y. Development of boost converter for Mirai. SAE Technical Paper. 2015, 2015-01-1170.

[4] Hydrogen Filling Stations in Europe www.netinform.net/ H2/H2Stations (accessed 17.03.2017).

[5] KOJIMA, K., SEKINE, S., Development trends and scenario for fuel cell vehicles. Toyota Technical Review. 2011, 57(2), 39.

Prof. Ireneusz Pielecha, DSc., DEng. - Faculty of Machines and Transport of Poznan University of Technology.

e-mail: Ireneusz.Pielecha@put.poznan.pl

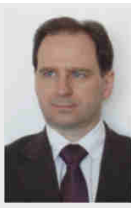

Wojciech Cieślik, MEng. - Faculty of Machines and Transport in Poznan University of Technology.

e-mail: Wojciech.Cieslik@put.poznan.pl
[6] MERKISZ, J., PIELECHA, I. Układy elektryczne pojazdów hybrydowych. Publishing House Poznan University of Technology, Poznań 2015.

[7] Outline of the Mirai. www.toyota-europe.com (accessed 14.03.2017).

[8] The Hybrid that Started it All. www.toyota-global.com (accessed 15.03.2017).

[9] YUMIYA, H., KIZAKI, M., ASAI, H. Toyota Fuel Cell System (TFCS). EVS28 International Electric Vehicle Symposium and Exhibition. Korea, 3-6.05.2016.

Andrzej Szałek, DEng. - New Technologies Expert, Toyota and Lexus Academy, Toyota Motor Poland. e-mail: Andrzej.Szalek@toyoyta.pl 